\title{
Marian Masternak
}

Uniwersytet Mikołaja Kopernika, Torun

m.masternak@interia.pl

\section{Marta Maria Masternak}

Uniwersytet Mikołaja Kopernika, Toruń

kancelaria@mmasternak.pl

\section{Charakter prawny działalności wykonywanej w dziedzinie publicznego transportu zbiorowego}

DOI: http://dx.doi.org/10.12775/SIT.2017.036

\section{Wstęp}

Potrzeba przemieszczania ludzi oraz ładunków towarzyszy człowiekowi od początku cywilizacji. W czasach współczesnych realizacja potrzeb transportowych ma niezmiernie istotne znaczenie, gdyż bez zapewnienia możliwości przemieszczania ludzi oraz ładunków nie byłby możliwy ani prawidłowy przebieg procesów gospodarczych, ani normalne funkcjonowanie jednostki w społeczeństwie. Nie dziwi więc fakt, że świadczenie usług w dziedzinie transportu stanowi bardzo ważny dział gospodarki, którego rozwój i prawidłowe funkcjonowanie pozostaje $\mathrm{w}$ sferze zainteresowania państwa i podlega prawnej regulacji. Dotyczy to zwłaszcza transportu pasażerskiego, w tym zbiorowego, którego funkcjonowanie - ze względu na jego społeczny wymiar - nie może opierać się wyłącznie na zasadach gospodarki wolnorynkowej, lecz odpowiedzialność za jego organizację i sprawne funkcjonowanie musi brać na siebie państwo. 
Jednym $z$ przejawów działalności państwa w tej dziedzinie jest stanowienie regulacji prawnych dotyczących organizacji i funkcjonowania transportu zbiorowego. W polskim systemie prawnym podstawowym aktem prawnym normującym te zagadnienia jest Ustawa $z$ dnia 16 grudnia 2010 r. o publicznym transporcie zbiorowym ${ }^{1}$ (dalej: u.o.p.t.z.). Reguluje zasady organizacji i funkcjonowania regularnego przewozu osób w publicznym transporcie zbiorowym wykonywanego na terytorium Rzeczypospolitej Polskiej oraz w strefie transgranicznej, w transporcie drogowym, kolejowym, innym szynowym, linowym, linowo-terenowym, morskim oraz w żegludze śródlądowej. Ponadto ustawa ta określa zasady finansowania regularnego przewozu osób w publicznym transporcie zbiorowym, w zakresie przewozów o charakterze użyteczności publicznej, realizowanego na terytorium Rzeczypospolitej Polskiej w zbiorowym transporcie publicznym. Wymieniona ustawa nie ma zastosowania do regularnego przewozu osób realizowanego w międzynarodowym transporcie drogowym oraz morskim, w międzynarodowej żegludze śródlądowej oraz w celach turystycznych. Odrębną regulacją objęty jest też transport lotniczy, którego funkcjonowanie zostało unormowane Ustawą z dnia 3 lipca 2012 r. Prawo lotnicze ${ }^{2}$. Należy zaznaczyć, że działalność w dziedzinie publicznego transportu zbiorowego podlega też przepisom zawartym w wielu innych aktach normatywnych, w tym w licznych aktach prawa europejskiego ${ }^{3}$, a także krajowego (np. w kodeksie cywilnym ${ }^{4}$, Ustawie $z$ dnia 15 listopada 1984 roku Prawo przewozowe ${ }^{5}$, Ustawie $z$ dnia 21 grudnia 2000 r. o żegludze śródlądowej ${ }^{6}$, Ustawie $z$ dnia 6 września 2001 r. o transporcie drogowym ${ }^{7}$, Ustawie $z$ dnia 18 września 2001 r. -

1 Tekst jednolity: Dz.U. z 2016 r., poz. 1867 ze zm.

2 Tekst jednolity: Dz.U. z 2017 r., poz. 959.

${ }^{3}$ Przepis art. 3 ust. 1 Ustawy o zbiorowym transporcie publicznym wymienia osiem aktów prawa wspólnotowego z zakresu transportu drogowego, kolejowego i morskiego, które należy uwzględniać przy stosowaniu przepisów tej ustawy.

${ }^{4}$ Ustawa z dnia 23 kwietnia 1964 r. Kodeks cywilny (tekst jednolity: Dz.U. z 2017 r., poz. 459 ze zm.).

${ }^{5}$ Dz.U. z 2015 r., poz. 915 ze zm.

${ }^{6}$ Tekst jednolity: Dz.U. z 2013 r., poz. 1458 ze zm.

7 Tekst jednolity: Dz.U. z 2016 r., poz. 1907 ze zm. 
Kodeks morski ${ }^{8}$, Ustawie $\mathrm{z}$ dnia 28 marca 2003 r. o transporcie kolejowym $^{9}$, Ustawie $z$ dnia 2 lipca 2004 r. o swobodzie działalności gospodarczej ${ }^{10}$, Ustawie $z$ dnia 18 sierpnia 2011 r. o bezpieczeństwie morskim ${ }^{11} \mathrm{i}$ innych aktach). Ogromne rozproszenie tych przepisów oraz przynależność do rozmaitych gałęzi prawa powoduje oczywiste trudności w ustaleniu charakteru prawnego zadań $\mathrm{z}$ zakresu zbiorowego transportu publicznego. W szczególności nie jest jasne, czy wykonywanie działalności w tej dziedzinie przez uprawnione podmioty należy zaliczać do sfery prawa prywatnego, czy nie należałoby raczej traktować jej jako zadanie publiczne, którego realizacja poddana została w pewnym zakresie reżimowi prawa prywatnego, a w pewnym - prawa administracyjnego. $Z$ tym zagadnieniem wiąże się inne pytanie - czy podmiot świadczący usługi w dziedzinie publicznego transportu zbiorowego powinien być uznawany wyłącznie za podmiot prowadzący określoną komercyjną działalność gospodarczą, czy też należałoby przypisywać mu cechy podmiotu upoważnionego do wykonywania zadań administracyjnych. Udzielenie odpowiedzi na te pytania ma istotne znaczenie nie tylko teoretyczne, lecz również praktyczne, ustalenie bowiem charakteru tych zadań rzutuje na ocenę charakteru stosunków prawnych nawiązywanych między stronami usług transportowych, a to $z$ kolei może mieć znaczenie choćby dla trybu rozstrzygania sporów między tymi stronami.

Rozważania zawarte w niniejszym opracowaniu dotyczą działalności wykonywanej w zakresie publicznego transportu zbiorowego $\mathrm{w}$ rozumieniu powołanej ustawy o publicznym transporcie zbiorowym, która w art. 4 pkt 14 zdefiniowała to pojęcie jako powszechnie dostępny regularny przewóz osób wykonywany w określonych odstępach czasu i po określonej linii komunikacyjnej, liniach komunikacyjnych lub sieci komunikacyjnej. Poza zakresem rozważań pozostają zagadnienia $z$ zakresu innych dziedzin transportu, w tym transportu lotniczego, które $z$ uwagi na swoją specyfikę wymagają odrębnej analizy.

\footnotetext{
8 Tekst jednolity: Dz.U. z 2016 r., poz. 66 ze zm.

9 Tekst jednolity: Dz.U. z 2016 r., poz. 1727 ze zm.

10 Tekst jednolity: Dz.U. z 2016 r., poz. 1829 ze zm.

11 Tekst jednolity: Dz.U. z 2016 r., poz. 281 ze zm.
} 


\section{Pojęcie i zakres zadań publicznych}

W celu określenia charakteru działalności polegającej na wykonywaniu usług $\mathrm{w}$ dziedzinie publicznego transportu zbiorowego należałoby w pierwszej kolejności podjąć próbę ustalenia, czy jest to jeden $z$ rodzajów komercyjnej działalności gospodarczej, poddanej wyłącznie reżimowi prawa prywatnego, czy też ma ona charakter zadania publicznego albo jak to się też często ujmuje, zadania administracji publicznej, którego wykonywanie opiera się na przepisach zarówno prawa prywatnego, jak i administracyjnego. Udzielenie odpowiedzi na to pytanie nie jest zadaniem łatwym, tak samo jak nie jest łatwe przeprowadzenie dystynkcji między sferą aktywności prywatnej i publicznej. Podstawowym kryterium, jakie można przyjąć do rozgraniczenia tych dwóch sfer, jest to, kto, w czyich sprawach oraz w czyim interesie prowadzi określoną działalność. Można przyjąć, że działalność prywatna podejmowana jest przez jednostkę w związku $z$ jej własnymi sprawami lub sprawami osób trzecich albo inaczej mówiąc - w interesie własnym lub w interesie osób trzecich, natomiast za publiczną należy uznać organizatorską działalność państwa podejmowaną w interesie publicznym, służącą realizacji celów publicznych. Pojawia się tutaj kolejne, szeroko w nauce prawa administracyjnego dyskutowane i niemające ustalonego znaczenia, pojęcie interesu publicznego. Mając świadomość ogromnej złożoności tego zagadnienia i pomijając analizę tego pojęcia, na potrzeby niniejszego opracowania można w uproszczeniu przyjąć, że interes publiczny oznacza dobro wspólne, dobro ogólne. Do zadań publicznych można zatem zaliczyć te, które służą realizacji tak rozumianego interesu publicznego. Zasadniczo są one realizowane przez państwo oraz wskazane przez państwo podmioty, a działalność prowadzona w celu wykonania tych zadań nazywana jest „administrowaniem” 12 .

Takie ogólne określenie istoty zadań publicznych nie pozwala jeszcze na ustalenie ich zakresu, a tym samym na udzielenie od-

12 Zob. J. Zimmermann, Prawo administracyjne, Warszawa 2014, s. 30. 
powiedzi na pytanie, czy do kategorii zadań publicznych należy wykonywanie działalności w dziedzinie zbiorowego transportu publicznego. W literaturze prawniczej brak jest jednolitości poglądów co do tego, jakie zadania należy zaliczać do publicznych ${ }^{13}$. Zwraca się przy tym uwagę na to, że zakres ten jest względny zarówno w czasie, jak i w przestrzeni, gdyż w pewnych krajach i w pewnym czasie określone działania władzy publicznej będą kwalifikowane jako zadania publiczne, w innym zaś miejscu lub czasie te same działania nie będą miały tego przymiotu ${ }^{14}$. Jak zauważa Małgorzata Stahl, na treść i zakres tychże zadań mają wpływ procesy globalizacji, rozwój cywilizacyjny, dostosowywanie do prawa unijnego, ale również prywatyzacja i komercjalizacja ${ }^{15}$. Ponadto przy założeniu, że zadania publiczne mają służyć dobru wspólnemu (interesowi publicznemu), to na kształtowanie jego zakresu będzie miała wpływ przyjmowana i realizowana $\mathrm{w}$ danym czasie i miejscu określona koncepcja interesu publicznego ${ }^{16}$, która - jak trafnie zauważa Jan Zimmermann - w głównej mierze uzależniona jest od czynników politycznych ${ }^{17}$.

Dla określenia zakresu pojęcia zadań publicznych użyteczne może okazać się spostrzeżenie Stanisława Biernata ${ }^{18}$, że zadania

${ }^{13}$ Poglądy nauki niemieckiej i polskiej na to pojęcie prezentuje R. Stasikowski, O pojęciu zadań publicznych (studium z zakresu nauki administracji i nauki prawa administracyjnego), „Samorząd Terytorialny” 2009, nr 7-8, s. 5 i n.

${ }^{14}$ H. Izdebski, Samorzad terytorialny. Podstawy ustroju i działalności, Warszawa 2011 , s. 148.

${ }^{15}$ M. Stahl, Wykonywanie zadań publicznych $w$ interesie publicznym $i$ władztwo jako cechy podmiotów administrujacych, w: System prawa administracyjnego. Podmioty administrujące, red. R. Hauser, Z. Niewiadomski, A. Wróbel, t. 6, Warszawa 2011 , s. 35.

${ }^{16}$ Na tę kwestię zwraca uwagę też M. Małecka-Łyczak, która pisze, że „zadania publiczne są kształtowane na podstawie przyjmowanej i realizowanej wizji interesu publicznego i mają prowadzić do jego osiągnięcia”. Zob. M. Małecka-Łyczak, Pojęcie i podziały zadań publicznych ze szczególnym uwzględnieniem zadań samorządu terytorialnego, „Zeszyty Naukowe Uniwersytetu Ekonomicznego w Krakowie” 2013, nr 921, s. 57.

17 Zob. J. Zimmermann, op. cit., s. 30.

18 S. Biernat, Prywatyzacja zadań publicznych. Problematyka prawna, Warszawa 1994. 
te mogą być ujmowane w trojaki sposób. Pojęcie to można odnosić do zadań rzeczywiście wykonywanych przez organy państwowe i samorządowe. W tym ujęciu chodzi o sferę rzeczywistości społecznej, a nie powinność realizowania określonych zadań. Drugie ujęcie polega na traktowaniu zadań publicznych jako swoistych i charakterystycznych dla państwa, wynikających z konstytucji oraz innych doniosłych ustaw ustrojowych ${ }^{19}$. Są to zadania niejako z natury przypisane państwu, określane w literaturze niemieckiej mianem zadań „minimalnych” lub „wrodzonych” państwa ${ }^{20}$. Zakres tak rozumianych zadań publicznych jest zmienny w czasie i różni się w poszczególnych ustrojach. Niektóre z nich są charakterystyczne dla każdego państwa (np. zabezpieczenie bezpieczeństwa wewnętrznego i porządku wewnętrznego), natomiast w przypadku innych zadań mogą pojawiać się wątpliwości, czy należy traktować je jako charakterystyczne dla państwa, czy też ich realizacja przez państwo zależy od wyboru politycznego ${ }^{21}$. Trzecie ujęcie zadań publicznych polega na obejmowaniu tym pojęciem wszelkich zadań państwa i samorządu wynikających $z$ całego obowiązującego porządku prawnego ( $\mathrm{z}$ konstytucji, ustaw oraz aktów normatywnych niższego rzędu) ${ }^{22}$. Ten ostatni sposób rozumienia zadań publicznych wydaje się najbardziej użyteczny do analizy problematyki podjętej w niniejszym opracowaniu. Opierając się na takim pojmowaniu zadań publicznych, ich zakres należy ustalać na płaszczyźnie obowiązującej regulacji prawnej. W pierwszej kolejności trzeba wziąć pod uwagę postanowienia Konstytucji RP, które zdaniem Magdaleny Małeckiej-Łyszczek pozwalają na wyróżnienie dwóch kategorii zadań publicznych. Pierwsza $z$ nich to sprawy polityki państwa, które stanowią grupę zadań publicznych dotyczących kwestii o charakterze ogólnopaństwowym. Ich wykonywanie należy na zasadzie domniemania do kompetencji Rady Ministrów, kierującej administracją

19 Ibidem, s. 16.

20 J. Grabbe, Verfassungsrechtliche Grenzen der Privateisierung kommunaler Aufgaben, Berlin 1979, s. 37, cyt. za: S. Biernat, op. cit., s. 16, przypis 11.

${ }^{21}$ S. Biernat, op. cit., s. 16.

22 Jak pisze S. Biernat, „suma ustalonych w ten sposób zadań daje obraz normatywnie nakazanej działalności państwa”. Ibidem, s. 16. 
rządową (art. 146 Konstytucji RP). Natomiast druga kategoria zadań publicznych to zadania wykonywane na poziomie struktur samorządu terytorialnego. W tej grupie mieszczą się zadania, których realizacja związana jest ściśle $z$ potrzebami mieszkańców danego terenu, a tym samym wymaga jak najszerszego uwzględnienia i wyartykułowania interesu reprezentowanego przez daną wspólnotę mieszkańców ${ }^{23}$.

\section{Publiczny transport zbiorowy jako zadanie publiczne}

Na podstawie przepisów normujących zasady organizacji i funkcjonowania przewozu osób w zbiorowym transporcie publicznym można stwierdzić, że ustawodawca powierzył zadania w tej dziedzinie trzem kategoriom podmiotów:

- podmiotom pełniącym funkcję organizatora tego transportu, do których należą: minister właściwy do spraw transportu, jednostki samorządu terytorialnego (gminy, powiaty i województwa) oraz związki samorządowe (związki międzygminne, związki powiatów, związki powiatowo-gminne, związki metropolitalne),

- podmiotom mającym status operatora publicznego transportu zbiorowego, do których należą: samorządowy zakład budżetowy oraz uprawniony do prowadzenia działalności gospodarczej w zakresie przewozu osób przedsiębiorca, który zawarł $\mathrm{z}$ organizatorem publicznego transportu zbiorowego umowę o świadczenie usług $\mathrm{w}$ zakresie publicznego transportu zbiorowego, na linii komunikacyjnej określonej w umowie,

- przewoźnikom, którymi są przedsiębiorcy uprawnieni do prowadzenia działalności gospodarczej w zakresie przewozu osób na podstawie potwierdzenia zgłoszenia przewozu, a w transporcie kolejowym - na podstawie decyzji o przyznaniu otwartego dostępu.

${ }^{23}$ M. Małecka-Łyszczek, Pojęcie i podziały zadań publicznych, s. 59-60. 
Nie ma najmniejszych wątpliwości, że zadania wykonywane przez pierwszą kategorię podmiotów mają charakter zadań publicznych (administracyjnych) - jest to bowiem działalność prowadzona dla dobra wspólnego (polega na zapewnieniu powszechnie dostępnego regularnego przewozu osób wykonywanego w określonych odstępach czasu i po określonej linii komunikacyjnej, liniach komunikacyjnych lub sieci komunikacyjnej), realizowana przez podmioty administracji publicznej (ministra właściwego do spraw transportu, jednostki samorządu terytorialnego oraz ich związki). Stanowisko to opiera się na powszechnym w doktrynie przekonaniu, że charakter zadań publicznych mają zadania należące do organów administracji publicznej, jak również wszystkie zadania wykonywane przez jednostki samorządu terytorialnego. Pogląd ten potwierdza orzecznictwo Trybunału Konstytucyjnego, który w uchwale $z$ dnia 27 września 1993 r. stwierdził, że „wszystkie zadania samorządu terytorialnego mają charakter zadań publicznych w tym znaczeniu, że służą zaspokojeniu potrzeb zbiorowych społeczności czy to lokalnych, w wypadku zadań własnych, czy zorganizowanego w państwo całego społeczeństwa, jak w wypadku zadań zleconych"24.

Naszym zdaniem publiczny charakter ma również działalność przewozowa realizowana przez operatora publicznego transportu zbiorowego, mającego status samorządowego zakładu budżetowego. Możliwość wykonywania przez ten podmiot wskazanej działalności wynika expressis verbis $\mathrm{z}$ art. 19 ust. 2 u.o.z.t.p., który stanowi, że „organizator może realizować przewozy w ramach publicznego transportu zbiorowego w formie samorządowego zakładu budżetowego". W świetle przepisów Ustawy z dnia 27 sierpnia 2009 r. o finansach publicznych $^{25}$ samorządowy zakład budżetowy jest jednostką sektora finansów publicznych, za pośrednictwem której, jednostka samorządu terytorialnego może wykonywać zadania własne, w tym zadania w zakresie interesującego nas tutaj lokalnego transportu

${ }^{24}$ Zob. uchwała Trybunału Konstytucyjnego z dnia 27.09.1993 r., W 10/93, OTK 1994, cz. II, poz. 46, s. 191-194. Takie stanowisko przyjął też SN w postanowieniu z dnia 26.09.1996 r., III ARN 45/96, „Orzecznictwo Sądu Najwyższego. Izba Administracyjna, Pracy i Ubezpieczeń Społecznych” 1997, nr 8, poz. 125.

${ }^{25}$ Tekst jednolity: Dz.U. z 2016 r., poz. 195 ze zm. 
zbiorowego. W myśl art. 15 ust. 1 wymienionej ustawy samorządowy zakład budżetowy odpłatnie wykonuje zadania, pokrywając koszty swojej działalności z przychodów własnych. W doktrynie i orzecznictwie wskazuje się, że samorządowy zakład budżetowy nie jest przedsiębiorcą ${ }^{26}$, lecz stanowi formę prawa budżetowego i mimo wyodrębnienia organizacyjnego, majątkowego i finansowego nie ma osobowości prawnej27. Zasadny jest zatem pogląd, że samorządowy zakład budżetowy stanowi formę realizacji zadań przez jednostkę samorządu terytorialnego. Wykonywane przez ten podmiot zadania, w tym $z$ zakresu lokalnego transportu zbiorowego, są $w$ istocie rzeczy zadaniami jednostki samorządu terytorialnego i tym samym mają charakter publiczny.

Bardziej złożonym zagadnieniem jest ustalenie charakteru zadań wykonywanych w dziedzinie zbiorowego transportu publicznego przez operatorów oraz przewoźników mających status podmiotów prywatnych. Według przepisów ustawy o zbiorowym transporcie publicznym przedsiębiorca uprawniony do prowadzenia działalności gospodarczej w zakresie przewozu osób nabywa status operatora publicznego transportu zbiorowego na podstawie zawartej z nim przez organizatora publicznego transportu zbiorowego umowy o świadczenie usług $\mathrm{w}$ zakresie publicznego transportu zbiorowego na linii komunikacyjnej określonej w tej umowie. $Z$ kolei nabycie przez przedsiębiorcę uprawnień do wykonywania przewozu osób $\mathrm{w}$ zakresie publicznego transportu zbiorowego niebędącego przewozem o charakterze użyteczności publicznej następuje na podstawie zgłoszenia o zamiarze wykonywania takiego przewozu do organizatora właściwego ze względu na obszar lub zasięg przewozów oraz wydanego przez tego organizatora potwierdzenia zgłoszenia przewozu. Wyjątek stanowi przewóz osób w transporcie kolejowym w zakresie publicznego transportu zbiorowego niebędący przewozem o charakterze użyteczności publicznej, który może być wykonywany przez przedsiębiorcę na podstawie decyzji o przyznaniu otwartego dostępu (art. 31 u.o.z.t.p.).

${ }^{26}$ Zob. L. Lipiec-Warzecha, Ustawa o finansach publicznych. Komentarz, Lex 2011.

${ }^{27}$ Wyrok WSA z dnia 6.07.2005 r., VI SA/Wa 2083/04, Lex nr 190634. 
W celu określenia charakteru powierzonych przedsiębiorcom w tej formie zadań w dziedzinie zbiorowego transportu publicznego warto odwołać się do poglądów doktryny dotyczących systemu podmiotów administrujących oraz roli, jaką w tym systemie odgrywać mogą podmioty prywatne. Punktem wyjścia do charakterystyki tego systemu jest konstatacja, że wykonywanie zadań publicznych należy do państwa, które uznawane jest za pierwotny podmiot administracji ${ }^{28}$. Jak wskazuje się w doktrynie niemieckiej, państwo posiada pierwotną władzę zwierzchnią, gdyż swojego istnienia ani kompetencji nie wywodzi od żadnego innego podmiotu ${ }^{29}$. Państwo realizuje należące do niego zadania administracyjne częściowo w sposób bezpośredni przez swoje organy, a częściowo przez inne podmioty, do których należą zarówno osoby prawa publicznego, jak i prawa prywatnego. Osobami prawa publicznego są - oprócz państwa - jednostki administracyjne posiadające mniejszą lub większą samodzielność względem państwa, co pozwala im na wykonywanie administracji na własną odpowiedzialność. Jednak podmioty te są związane $z$ państwem, gdyż ich byt i zadania pochodzą od państwa, w swojej działalności opierają się na ustawach pochodzącymi od państwa, a ponadto podlegają kontroli sprawowanej przez państwo. Do tego rodzaju podmiotów Hartmut Maurer zalicza korporacje, zakłady i fundacje ${ }^{30}$, które to jednostki uważane są za podmioty administracji pośredniej (zdecentralizowanej) ${ }^{31}$. W polskim systemie ustrojowym wśród tych podmiotów niewątpliwie znajdują się m.in. wspomniane jednostki samorządu terytorialnego (gminy, powiaty i województwa) oraz związki samorządowe (związki międzygminne, związki powiatów, związki powiatowo-gminne, związki metropolitalne), które - w myśl ustawy o publicznym transporcie zbiorowym realizują zadania publiczne m.in. w dziedzinie interesującego nas tutaj zbiorowego transportu publicznego.

28 E. Ochendowski, Prawo administracyjne. Część ogólna, Torun 2013, s. 241 .

${ }_{29}$ Zob. H. Maurer, Ogólne prawo administracyjne. Allgemeine Verwaltungsrecht, przeł. K. Nowacki, Wrocław 2003, s. 230.

${ }^{30}$ Ibidem, s. 231.

31 E. Ochendowski, op. cit., s. 241. 
W nauce prawa administracyjnego przyjmowana jest koncepcja, według której państwo nie wykonuje wszystkich zadań publicznych przez własne organy bądź przez powołany przez siebie podmioty prawa publicznego, w tym przez wspomniane samorządy, lecz w pewnej określonej, chociaż najczęściej bardzo ograniczonej części, powierza ich realizację osobom prywatnym (osobom fizycznym lub osobom prawnym prawa prywatnego). Podmioty takie, nazywane w literaturze niemieckiej „osobami upoważnionymi” lub „wykonującymi funkcje zlecone przedsiębiorcami”, wraz z przeniesieniem na nich przez państwo określonych zadań administracyjnych uzyskują uprawnienia władcze, wykonują powierzone im zadania samodzielnie i działają na własną odpowiedzialność. Dlatego zaliczane są do podmiotów administracji w szerokim znaczeniu ${ }^{32}$. Zlecanie podmiotom prywatnym zadań administracyjnych stanowi formę decentralizacji administracji publicznej i wiąże się na ogół $\mathrm{z}$ przyznaniem tym podmiotom pewnych uprawnień $\mathrm{w}$ zakresie stosowania środków właściwych dla administracji publicznej, tj. srodków władczych. Koncepcja powierzania osobom prywatnym zadań publicznych wraz z przekazywaniem im takich uprawnień pojawiła się już w XIX w. na gruncie francuskiego modelu koncesji robót publicznych (concession de travaux public) ${ }^{33}$, a później służby publicznej (concession de service public) ${ }^{34}$. W polskim systemie prawa również występuje zjawisko powierzania funkcji admini-

32 Zob.: H. Maurer, op. cit., s. 231-232; E. Ochendowski, op. cit., s. 242.

${ }^{33}$ Koncesja ta polegała na powierzeniu przez państwo, w drodze umowy, osobie prywatnej wykonania określonych robót publicznych (np. budowy urządzeń infrastruktury technicznej służących zaspokajaniu potrzeb publicznych), co wiązało się z przyznaniem koncesjonariuszowi pewnych uprawnień władczych, np. w zakresie wywłaszczania. Zob. H. Berthelemy, Traite Elementare de Droit Administratif, Paris 1926, s. 707.

${ }^{34}$ Istota tej koncesji polega na tym, że udzielający koncesji w drodze kontraktu zobowiązuje drugą osobę do prowadzenia służby publicznej na własny koszt i ryzyko, pozwalając jej jednocześnie na czerpanie korzyści poprzez pobieranie opłat od użytkowników. Zob.: G. Feiser, Droit Administratif, Paris 1979, s. 106 ; Y. Gaudemet, Droit Administratif, Paris 2005, s. 330 i n. oraz podana tam literatura. Podobnie rozumiano koncesję służby publicznej w starszej literaturze francuskiej. Zob. np. G. Jeze, Les Principes generaux du Droit Administratif, Paryż 1926, s. 342. 
stracji publicznej podmiotom prawa prywatnego. W okresie PRL miało miejsce zlecanie funkcji organów administracji wyłącznie na rzecz organizacji społecznych ${ }^{35}$, natomiast współcześnie - zadania administracji powierzane są także innym podmiotom prawa prywatnego. Są to podmioty bardzo zróżnicowane pod względem podstawy i przedmiotu działania, celu ich utworzenia konstrukcji prawnej i form działalności ${ }^{36}$. Zbigniew Cieślak dzieli je na dwie grupy: podmioty państwowe i niepaństwowe, a w tej drugiej wymienia stowarzyszenia, związki wyznaniowe, związki zawodowe, spółdzielnie, spółki prawa handlowego ${ }^{37}$. Z kolei Małgorzata Stahl wyróżnia podmioty prywatne i podmioty społeczne ${ }^{38}$.

W doktrynie prawa administracyjnego panuje przekonanie, że w zakresie, w jakim przepisy prawa przyznają podmiotom prywatnym prawo wykonywania funkcji administracji publicznej, zaliczane są do podmiotów administracji, wchodzących w skład aparatu administracyjnego ${ }^{39}$. Należy przy tym zaznaczyć, że traktowanie organizacji prywatnoprawnych jako podmiotów administracji publicznej jest kwestią umowną i zależy od przyjętej siatki pojęciowej. Decydujące znaczenie ma to, czy pojęcie podmiotu administracyjnego zostanie ograniczone do podmiotów opartych na prawie publicznym, czy będzie rozciągnięte na wszystkie prawnie samodzielne organizacje i podmioty realizujące zadania administracji ${ }^{40}$.

Biorąc pod uwagę powyższe ustalenia, można przyjąć, że podmioty prywatne, które wykonują zadania w dziedzinie zbiorowego transportu publicznego w charakterze operatorów usług oraz przewoźników, w istocie rzeczy realizują zadania administracyjne, i tym samym powinny być traktowane jako podmioty administracji („osoby upoważnione”). Zadania te, mają taki sam charakter prawny, jak

35 Zob. Z. Leoński, Zarys prawa administracyjnego, Warszawa 2004, s. 86.

${ }^{36}$ Zob. Z. Cieślak, w: Z. Niewiadomski, Z. Cieślak, I. Lipowicz, G. Szpor, Prawo administracyjne, red. Z. Niewiadomski, Warszawa 2009, s. 209.

37 Ibidem.

${ }^{38}$ M. Stahl, Inne podmioty administracyjne, w: System prawa administracyjnego, s. 530 .

39 Zob. np. M. Wierzbowski, A. Wiktorowska, w: Prawo administracyjne, red. M. Wierzbowski, Warszawa 2015, s. 78-79.

${ }^{40}$ Zob. H. Maurer, op. cit., s. 233. 
zadania realizowane $\mathrm{w}$ tej dziedzinie przez podmioty prawa publicznego (ministra do spraw transportu, jednostki samorządu terytorialnego oraz ich związki). Nie byłoby logiczne stanowisko, że inny charakter ma działalność przewozowa prowadzona przez jednostkę samorządu terytorialnego, realizowana przez samorządowy zakład budżetowy, a inny ta sama działalność wykonywana przez przewoźnika prywatnego. Należy podzielić stanowisko Stanisława Biernata, że przekazanie wykonywania zadań publicznych podmiotom niepublicznym nie powoduje, że przestają być ujmowane w kategorii zadań publicznych ${ }^{41}$. Autor ten trafnie wskazuje, że podstawowym kryterium uznania konkretnego zadania za zadanie publiczne powinno być ponoszenie odpowiedzialności za jego realizację przez administrację publiczną (czy to na szczeblu rządowym, czy samorządowym), nawet jeśli wykonawca sytuuje się poza strukturami administracji. Za takim podejściem opowiada się też orzecznictwo, w którym ukształtowało się stanowisko, że wykonywanie zadania publicznego przez podmiot prawa prywatnego (np. w oparciu o zawartą umowę) nie powoduje, że samo zadanie przestaje mieć charakter publiczny, jak również nie oznacza przejścia podmiotu wykonującego zadanie do sektora podmiotów prawa publicznego ${ }^{42}$. Jak trafnie zauważa Małgorzata Stahl, „podmiot niepubliczny, wykonując zadania administracji publicznej, pozostaje podmiotem prywatnym, ale $\mathrm{w}$ sensie funkcjonalnym ma charakter podmiotu administrującego i staje się - $\mathrm{w}$ tym jedynie zakresie - podmiotem administrującym, elementem funkcjonalnie rozumianego systemu administracji publicznej" ${ }^{43}$. Podzielając ten pogląd, można przyjąć, że prywatni operatorzy oraz przewoźnicy realizujący zadania $\mathrm{w}$ dziedzinie zbiorowego transportu drogowego mającego - jak wyżej wskazano - charakter zadań publicznych, powinni być zaliczani do szeroko rozumianego systemu podmiotów administrujących. Nie zmienia tego fakt, że bezpośrednie świadczenie usług przez te podmioty następuje w formach cywilnoprawnych.

\footnotetext{
${ }^{41}$ S. Biernat, op. cit., s. 25-34.

${ }^{42}$ Wyrok SN z dnia 13.07.2012 r., III SK 44/2011, LexPolonica nr 4305684.

${ }^{43}$ Zob. M. Stahl, Inne podmioty administracyjne, s. 536.
} 
W nauce prawa administracyjnego powszechny jest pogląd, że administracja publiczna może wykonywać swoje zadania publiczne nie tylko w formach właściwych prawu administracyjnemu, lecz może też stosować formy prawa cywilnego, m.in. przez posługiwanie się cywilnoprawnymi formami działania (np. umową). Trafne jest tu spostrzeżenie Jerzego Starościaka, że funkcje administrowania tworzy cały łańcuch czynności, opartych na normach przynależącymi do różnych gałęzi prawa, a „prawo administracyjne rządzi tylko częścią funkcji administrowania”44.

Na marginesie warto zaznaczyć, że posłużenie się przez administrację formami prawa cywilnego może polegać nie tylko na stosowaniu cywilnoprawnych form działania, lecz także na tworzeniu przez podmioty administrujące osób prawa prywatnego i powierzanie im wykonania określonych zadań administracyjnych. W polskim systemie prawnym będą to spółki prawa handlowego, powoływane w celu realizacji określonych zadań komunalnych. W interesującej nas dziedzinie publicznego transportu zbiorowego mogą to być np. przedsiębiorstwa komunikacyjne tworzone przez gminy w formie spółek akcyjnych lub spółek $z$ ograniczoną odpowiedzialnością. Podmioty, o których mowa, jako osoby zorganizowane na podstawie prawa prywatnego, są odrębnymi podmiotami prawa, które samodzielnie prowadzą określoną działalność, jednak jak pisze Hartmut Maurer, w rzeczywistości tego rodzaju osoby prawie zawsze kierowane są przez podmiot publicznoprawny, który je utworzył i który posiada wszystkie lub większość udziałów lub akcji ${ }^{45}$. Trafne jest przy tym stanowisko Eugeniusza Ochendowskiego, że osoby prawa prywatnego, o których tu mowa, różnią się od „podmiotów upoważnionych" tym, że są utworzone przez podmiot publicznoprawny. Jeśli jednak taka osoba prawa prywatnego zostanie upoważniona do wykonywania określonych zadań publicznych w formach władczych, to nabędzie status „podmiotu upoważnionego" ${ }^{46}$.

${ }^{44}$ J. Starościak, Studia $\mathrm{z}$ teorii prawa administracyjnego, Wrocław-Warszawa-Kraków 1967, s. 61.

${ }^{45}$ Zob. H. Maurer, op. cit.,s. 233.

${ }^{46}$ E. Ochendowski, op. cit., s. 242-243. 


\section{Prywatyzacja a charakter zadań w dziedzinie zbiorowego transportu drogowego}

Relacja między pojęciem zlecania zadań administracyjnych podmiotom prywatnym a coraz powszechniej używaną w piśmiennictwie prawniczym prywatyzacją zadań publicznych ujmowana jest w literaturze dwojako. Według pierwszego stanowiska są to dwa różne pojęcia, których nie można utożsamiać. Zlecanie zadań publicznych stanowi formę zewnętrznej dekoncentracji administracji publicznej, natomiast prywatyzacja prowadzi do całkowitego wyeliminowania odpowiedzialności państwa, ,a zatem wymusza deregulację zajmowanego obszaru aktywności, w konsekwencji eliminując przestrzeń do działania administracji publicznej”47. W drugim zaś ujęciu zlecanie zadań publicznych podmiotom prywatnym traktowane jest jako przejaw prywatyzacji tych zadań, którą uznaje się za jedną $z$ form decentralizacji administracji publicznej i zbliżania tej administracji do obywatela, co jest zgodne $z$ powszechnie przyjmowaną w państwach rozwiniętych zasadą subsydiarności ${ }^{48}$. W ten sposób rozumiana prywatyzacja zadań publicznych może występować $\mathrm{w}$ dwóch postaciach: mianowicie może mieć charakter formalny bądź materialny ${ }^{49}$. Prywatyzacja formalna polega na tym, że administracja realizuje określone zadania publiczne $\mathrm{w}$ formach przewidzianych przez prawo prywatne bądź państwo zleca wykonywanie zadań administracyjnych podmiotom prywatnoprawnym albo też administracja tworzy podmioty o takim charakterze dla wykonywania zadań publicznych. $Z$ kolei prywatyzacja materialna ma miejsce wtedy, gdy administracja całkowicie zaprzestaje wyko-

47 Zob. J. Niczyporuk, Decentralizacja administracji publicznej, Lublin 2006, s. 146 i 148.

${ }^{48}$ Zob. J. Zimmermann, op. cit., s. 166.

${ }^{49}$ Zob. H. Maurer, op. cit.,s. 234. Podobnego podziału prywatyzacji dokonuje Zimmermann, który wyróżnia prywatyzację całkowitą, oznaczającą - zdaniem tego autora - utratę przez dane zadanie charakteru publicznego, oraz częściową, polegającą jedynie na oddzieleniu odpowiedzialności za wykonania zadań od ich bezpośredniego realizowania. Zob. J. Zimmermann, op. cit., s. 166. 
nywania określonych zadań publicznych i pozostawia je działalności podmiotów prywatnych. Jednak - jak zauważa Hartmut Maurer jeśli podmiot prywatny przez wykonywanie zleconych funkcji administracyjnych zostaje zobowiązany do realizowania dotychczasowych zadań administracyjnych, to staje się „osobą upoważnioną”, a tym nabywa status podmiotu administracji ${ }^{50}$.

Naszym zdaniem powierzenie podmiotom prywatnym zadań w dziedzinie zbiorowego transportu drogowego można traktować jako przejaw prywatyzacji formalnej. Jak bowiem wynika z przepisów normujących tę dziedzinę administracji publicznej, zlecenie przewoźnikom prywatnym zadań administracyjnych nie zwalnia organów administracji rządowej i samorządowej pełniących funkcję organizatorów zbiorowego transportu publicznego $z$ odpowiedzialności za prawidłową ich realizację. Organy te już na etapie zlecania zadań $z$ dziedziny zbiorowego transportu publicznego kontrolują, czy podmioty ubiegające się o uzyskanie statusu operatora lub przewoźnika zbiorowego transportu publicznego spełniają ustawowe warunki prowadzenia w tym zakresie działalności. Organy administracji rządowej i samorządowej pełniące funkcję organizatorów zbiorowego transportu publicznego sprawują też kontrolę prawidłowości realizacji zadań powierzonych operatorom i przewoźnikom, a $\mathrm{w}$ razie stwierdzenia naruszeń, mają prawo - $\mathrm{w}$ przypadkach określonych w ustawie - pozbawić te podmioty uprawnień do świadczenia usług przewozowych, np. w drodze rozwiązania zawartej $\mathrm{z}$ operatorem umowy o świadczenie usług w zakresie publicznego transportu zbiorowego lub cofnięcia przewoźnikowi potwierdzenia zgłoszenia przewozu (art. 35 ust. 4 u.o.z.t.p.).

\section{Podsumowanie}

Przedstawione w niniejszym opracowaniu rozważania uzasadniają naszym zdaniem wniosek, że działalność w dziedzinie zbiorowego transportu publicznego ma charakter zadań publicznych. Nie przeczy temu fakt, że jest ona wykonywana nie tylko przez organy ad-

${ }^{50}$ Zob. H. Maurer, op. cit., s. 234. 
ministracji publicznej, lecz również przez osoby prywatne, ani to, że w toku jej realizacji stosowane są różne prawne formy działania, zarówno administracyjnoprawne, jak i cywilnoprawne.

Zakwalifikowanie zadań $\mathrm{z}$ zakresu zbiorowego transportu publicznego do zadań publicznych rodzi szereg różnych konsekwencji. Po pierwsze, odpowiedzialność za prawidłową realizację tych zadań ponoszą organy administracji publicznej, odgrywające rolę organizatorów zbiorowego transportu publicznego. Na tych organach ciąży obowiązek zapewnienia prawidłowego funkcjonowania zbiorowego transportu publicznego, niezależnie od tego, jakim podmiotom: publicznym czy prywatnym, powierzono świadczenie usług przewozowych. Organy te, działając $\mathrm{w}$ prawnie określonych ramach, przesądzają o tym, komu powierzone zostaną zadania $z$ tego zakresu, a ponadto kontrolują realizację tych zadań. W przypadkach przewidzianych prawem mają możliwość pozbawienia danego podmiotu uprawnień do prowadzenia działalności w tej dziedzinie (np. w drodze wypowiedzenia umowy bądź cofnięcia potwierdzenia zgłoszenia działalności).

Drugą istotną konsekwencją zakwalifikowania zadań z zakresu zbiorowego transportu publicznego do zadań publicznych jest to, że powierzanie tych zadań podmiotom prywatnym należy traktować jako zlecanie im zadań administracji publicznej, przez co zostają one włączone do szeroko rozumianego systemu podmiotów administracji publicznej. Powierzenie zadań administracyjnych podmiotom prywatnym może wiązać się $\mathrm{z}$ wyposażeniem ich w uprawnienia do stosowania form właściwych dla administracji, w tym do stosowania władczych form działania. Przejawów dysponowania tego rodzaju uprawnieniami można upatrywać między innymi w upoważnieniu operatorów i przewoźników do wydawania regulaminów przewozu osób w zbiorowym transporcie publicznym. W doktrynie i orzecznictwie panuje wprawdzie zgodność stanowisk co do tego, że regulaminy te mają charakter wzorca umowy w rozumieniu przepisów prawa cywilnego, to jednak można mieć wątpliwości, czy rzeczywiście akty te mają wszystkie cechy cywilnoprawnej formy działania, czy też bliższe są one formom administracyjnoprawnym. Dyskusyjne jest też to, która $z$ tych dwóch form działania jest bardziej przydatna do regulowania stosunków prawnych między pod- 
miotem wykonującym publiczne usługi przewozowe i pasażerem. Zagadnienie to wymaga jednak odrębnej, poszerzonej analizy, co wykracza poza zakres niniejszego opracowania.

\section{STRESZCZENIE}

Charakter prawny działalności wykonywanej w dziedzinie publicznego transportu zbiorowego

W opracowaniu dokonano analizy charakteru prawnego działalności polegającej na wykonywaniu zbiorowego transportu publicznego. Zadania $\mathrm{w}$ tej dziedzinie wykonywane są przez organy administracji publicznej oraz osoby prywatne, przy zastosowaniu zarówno administracyjnoprawnych, jak i cywilnoprawnych form działania. Wszystkie te zadania mają charakter zadań publicznych, niezależnie od tego, czy wykonują je organy administracji publicznej, czy osoby prywatne. Powierzenie niektórych zadań z zakresu zbiorowego transportu drogowego podmiotom prywatnym nie powoduje zmiany charakteru prawnego tych zadań. Nadal są one zadaniami publicznymi, gdyż służą realizacji interesu publicznego, a ponadto odpowiedzialność za ich prawidłowe wykonanie ponoszą organy administracji publicznej.

Słowa kluczowe: publiczny transport zbiorowy; zadania publiczne; zlecanie zadań publicznych; prywatyzacja zadań publicznych

\section{SUMMARY}

The legal nature of public transport tasks

The study analyzes the legal nature of public transport. It has been established that tasks in this field are carried out by public administrations and private individuals, using both administrative and civilian forms of action. All these tasks are of a public nature whether they are carried out by public administrations or private individuals. The allocation of certain collective transport tasks to private parties does not change the legal nature of these tasks. They are still public tasks because they serve the public interest, and the responsibility for their proper performance is borne by the public administration. 
Keywords: public transport; public tasks; commissioning of public tasks; privatization of public tasks

\section{BIBLIOGRAFIA}

Berthelemy H., Traite Elementare de Droit Administratif, Paryż 1926.

Biernat S., Prywatyzacja zadań publicznych. Problematyka prawna, Warszawa 1994.

Cieślak Z., w: Z. Niewiadomski, Z. Cieślak, I. Lipowicz, G. Szpor, Prawo administracyjne, red. Z. Niewiadomski, Warszawa 2009.

Feiser G., Droit Administratif, Paryż 1979.

Gaudemet Y., Droit Administratif, Paryż 2005.

Grabbe J., Verfassungsrechtliche Grenzen der Privateisierung kommunaler Aufgaben, Berlin 1979.

Izdebski H., Samorzad terytorialny. Podstawy ustroju i działalności, Warszawa 2011.

Jeze G., Les Principes generaux du Droit Administratif, Paryż 1926.

Leoński Z., Zarys prawa administracyjnego, Warszawa 2004.

Lipiec-Warzecha L., Ustawa o finansach publicznych. Komentarz, Lex 2011.

Małecka-Łyczak M., Pojęcie i podziały zadań publicznych ze szczególnym uwzględnieniem zadań samorzadu terytorialnego, „Zeszyty Naukowe Uniwersytetu Ekonomicznego w Krakowie” 2013, nr 921.

Maurer H., Ogólne prawo administracyjne. Allgemeine Verwaltungsrecht, tłum. K. Nowacki, Wrocław 2003.

Niczyporuk J., Decentralizacja administracji publicznej, Lublin 2006.

Ochendowski E., Prawo administracyjne. Część ogólna, Torun 2013.

Stasikowski R., O pojęciu zadań publicznych (studium z zakresu nauki administracji i nauki prawa administracyjnego), „Samorząd Terytorialny” 2009, nr 7-8.

Stahl M., Inne podmioty administracyjne, w: System prawa administracyjnego. Podmioty administrujace, red. R. Hauser, Z. Niewiadomski, A. Wróbel, t. 6, Warszawa 2011.

Stahl M., Wykonywanie zadań publicznych $w$ interesie publicznym $i$ wtadztwo jako cechy podmiotów administrujacych, w: System prawa administracyjnego. Podmioty administrujace, red. R. Hauser, Z. Niewiadomski,

A. Wróbel, t. 6, Warszawa 2011.

Starościak J., Studia $z$ teorii prawa administracyjnego, Wrocław-Warszawa-Kraków 1967.

Wierzbowski M., Wiktorowska A., w: Prawo administracyjne, red. M. Wierzbowski, Warszawa 2015.

Zimmermann J., Prawo administracyjne, Warszawa 2014. 